\title{
RECONSTRUCTION OF TERTIARY PALAEOENVIRONMENTS USING A COMBINATION OF MOLECULAR AND CONVENTIONAL PALAEOBIOLOGY
}

HOOKER, Jerry J., Dept. of Palaeontology, Natural History Museum, London, SW7 5BD, U.K. (1); Van BERGEN*, Pim F., Organic Geochemistry Unit, Technical University Delft, De Vries van Heystpl. 2, 2628 RZ, Delft, Netherlands (2); and Dept. of Geology, Royal Holloway and Bedford New College, University of London, Egham, Surrey, TW20 0EX, U.K. (3); SINGER, Ros L., Dept. of Biology, Kings College London, Campden Hill Rd. London, W8 7AH, U.K. (4); COLLINSON, Margaret E., address (3); De LEEUW, Jan W., address (2); JONES, Tim P., address (3).

The Bembridge Limestone Formation (BLF), Late Eocene of Headon Hill, Isle of Wight, England, contains a diverse array of mammals (around $50 \mathrm{spp}$.) distributed through 10 levels. Its lower part ("lower fauna") marks the appearance of a significant number of species, genera and one family unknown from earlier English Late Eocene strata. Towards the top of the BLF there is a reversion to faunas ("upper fauna") more typical of the underlying Headon Hill Formation. This represents their last appearance in England. The succeeding Bembridge Marls Member fauna is similar to that in the lower part of the BLF. These changes are provincial in scale and may be climate induced (reflecting a slight warming followed by terminal Eocene cooling). Superimposed on these changes are smaller-scale more frequent fluctuations linked to alternating marl and black mud lithologies which may represent local habitat changes. In order to obtain overall understanding of the environment of deposition and taphonomic bias influencing these mammalian assemblages an integrated multidisciplinary study is being undertaken.

Plant macrofossils are unfortunately extremely rare in this sequence. Those few which are present typify the fresh-water marsh vegetation widespread in the Late Eocene/Early Oligocene of England. In contrast mammalian faunas indicate more wooded conditions. Seeds like those of the modern free-floating fresh-water plant Stratiotes occur in three levels. However, they are poorlypreserved. The chemical composition of the seed coat as revealed by flash pyrolysis gas chromatography indicates a very simple polyphenol macromolecule probably resulting from transformations of more complex polyphenols in well-preserved Stratiotes seeds.

Determinable palynomorphs are very rare and largely restricted to the part of the sequence which contains the "upper fauna". They suggest a tranquil fresh-water depositional setting as do several molluscs and charophytes. Palynomorphs also include fungal remains, fern spores and a few tree pollen, the latter possibly from regional vegetation. However, the bulk of the palynological organic matter consists of brown structureless organic matter (SOM), resin-like particles and "platy kerogen". In the lower beds, pale shelly muds with potamidids and corbiculids lack mammals and contain palynological organic matter dominated by resin-like particles and with abundant pyrite. These beds probably reflect brackish influence, the loss of which largely coincides with the reappearance of abundant mammals ("lower fauna"), occurrence of Stratiotes and of charophytes. Resin-like particles remain dominant in the palynological organic matter. "Platy kerogen" dominates three units including that containing the first occurrence of the "upper fauna". Subsequently resinlike particles again dominate. Brown SOM is scattered throughout but is well represented in two units one of which contains "lower fauna" the other "upper fauna".

Variations in palynological organic matter are reflected in the chemical composition of residues studied. Results from five black muds show that samples which mainly contain resin-like particles are dominated by $n$-alkanes and $n$-alk-1-enes in their pyrolysates. However, there is no indication of known resin chemical signatures. This indicates that the organic matter in these residues is mainly derived from cuticles (cutan) and/or cell wall remains (algaenan) of fresh-water algae. Samples containing "platy kerogen" and brown SOM are dominated by aromatics and phenols in their pyrolysates indicating an origin from woody materials. Work in progress on stable isotope analyses of the residues may further clarify the nature of the organic input. 